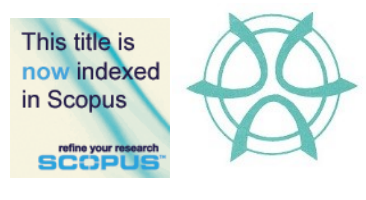

PLANNING MALAYSIA:

Journal of the Malaysian Institute of Planners

VOLUME 19 ISSUE 5 (2021), Page 192 - 205

\title{
THE CONTRIBUTIONS OF PUBLIC SPACE TO THE SOCIAL SUSTAINABILITY OF TRADITIONAL SETTLEMENTS
}

\author{
Nor Zalina Harun ${ }^{1} \&$ Najiha Jaffar $^{2}$ \& Mazlina Mansor $^{3}$ \\ ${ }^{1,2}$ UNIVERSITI KEBANGSAAN MALAYSIA \\ ${ }^{3}$ INTERNATIONAL ISLAMIC UNIVERSITY MALAYSIA
}

\begin{abstract}
Landscape is a dynamic system in geography that has a spatial structure created by natural and cultural causes. Landscapes are made up of geophysical, which are formed by physical terrain elements (mountains, hills and water bodies and streams), living elements (indigenous plants), man-made elements (land uses, buildings, and structures), and temporary elements such as lighting and weather conditions. Traditional settlements are one of the key cultural land-uses and landscape assets in terms of history, customs, culture, and architecture. Modernization and continuous development have sometimes radically altered the physical terrain environment over time, obliterating traditional settlements in favor of more modern land uses with public facilities. Will these facilities continue to operate as a social sustainability accelerator for residents living in traditional settlements? This research aims to address the roles of the public infrastructure in determining the social sustainability of the people in two traditional settlements in Kuala Terengganu. A mixed-methods strategy was used in this study, which comprised of observation and survey questionnaires. To identify the important components that determine social sustainability, a questionnaire survey was employed that collected data from 400 residents. The major conclusions emphasize three most significant characteristics of public space under the most preferred public infrastructures selected by the residents: They are: (i) adequate amenities; (ii) public spaces that support a variety of activities; and (iii) public spaces that are accessible to the general public. The research implicates that a better socio-cultural and traditional heritage will be generated and preserved as a result of a more organised settlement, underlining the value of culture and history in developing a sense of community and belonging.
\end{abstract}

Keywords: physical landscape; public spaces; social sustainability; traditional settlement

\footnotetext{
${ }^{1}$ Corresponding Author. Email: nzalina@ukm.edu.my
} 
PLANNING MALAYSIA

Journal of the Malaysia Institute of Planners (2021)

\section{INTRODUCTION}

The study aims to analyse how the multiple physical aspects of public infrastructure and traditional settlement environment around Kuala Terengganu play a role in supporting the welfare of the community. This is in line with a report from PlanMalaysia through the National Happiness Index Study 2018 and 2019, which lists Kuala Terengganu as one of the ten happiest places in Malaysia to live, achieving more than $90 \%$ of the index. The initial goal is to figure out the kinds of public infrastructure exist in traditional Malay settlements. The second goal is to examine the functions of public infrastructure in sustaining the traditional Malay settlement and the community's social sustainability.

A traditional settlement is one of the fundamental assets of significant value from the aspects of history, customs, culture, and architecture. It can help to shape a country's identity. The traditional Malay settlement in this study is defined as an area inherited and inhabited by the Malay community for generations. It is an integrated village environment with a Malay architectural character, and a physical landscape based on the Malay settlement concept (Pelan Induk Kampung Tradisional, 2011; Li Wei, 2015). Nonetheless, the existence of traditional settlements near modern cities is regarded as vulnerable and underdeveloped, potentially leading to their diminish for the sake of development. As a result, the traditional Malay settlement is also losing its identity. Malaysia in particular has undergone a rapid economic and social transformation, with many new developments are built in and around village land or traditional settlement areas since the late 1970s.

Consequently, the modernization and progress have changed the local way of life and identity over the years, directly and indirectly. The growth of new cities in the country has reduced the physical and cultural landscape, particularly in the traditional settlements (Ariffin, 2007). Similarly, the study discovered that Malaysia's rapid development of new cities after the country's independence had a significant impact on the structure of society, economy, social, and the environment of the local cultures. Several studies have found that the loss of local identity has increased, particularly in historic districts. As Relph asserted in his concept of 'placelessness' (1976), eventually the events damage the character of a place and eliminate the sense of place. The loss of local identity is caused by two major issues: the ambiguity of functions of the importance of the physical landscapes, and the changes in space patterns caused by development.

\section{LANDSCAPE AND PUBLIC INFRASTRUCTURE ELEMENTS}

A settlement's 'progressive' development is most often built without regard of the population's interests, thereby eliminating the community's social interaction in a place. This refers to the growing number of housing projects in rural areas that are constructed with disregard for Malay societal values and culture, which have been practised in the areas for generations. According to Rasdi (2011), the 
Nor Zalina Harun \& Najiha Jaffar \& Mazlina Mansor

The Contributions of Public Space to The Social Sustainability of Traditional Settlements

lack of space for activities of community ceremonies such as weddings and funeral arrangements is increasingly being overlooked by most newly built homes today. According to Ghoomi et al. (2015), the development of a modern city lowers the quality of social relations in a society and alters the physical pattern of the residential area.

Furthermore, one of the factors contributing to the decline on the importance of a traditional settlement's is a lack of research emphasising on the physical landscape of the settlements. Physical landscape elements are discovered to be important only in the context of municipal and recreational park studies. There have been very few studies on the conservation of physical landscapes in traditional settlements. As a result, only few people are well-versed in the functions and significance of the physical elements found in traditional settlements. As such, there is a cultural neglect or ignorance toward heritage conservation efforts. In general, everyone in a society, not just the authorities, must be aware of the importance of preserving cultural heritage elements.

Landscape is a dynamic system with a spatial structure generated by natural and cultural factors in geography (Bobek \& Schmithüsen, 1998). Landscape is made up of geophysically-formed physical elements of terrain such as mountains, hills, and water streams such as rivers, lakes, ponds, and seas. The living elements are such as the indigenous plants, and the man-made elements include various land uses, buildings, and structures. In addition, it has temporary elements such as light and weather conditions (McKean, 2005). According to Leibenath and Gailing (2012), landscape is: (1) a physical space or complex of ecosystems; (2) a context for the relationship between humans and the environment; (3) a figurative expression; and (4) a social construct or phrase used in everyday speech. Regarding the word 'physical landscape', Berglee (2012) defines it as a term used to describe any natural area on the planet. According to Pickering (1994), a physical landscape functions as a component of the cultural landscape, fusing the physical landscape with the social landscape immortalised as a model to ensure that location and life coexist together on both symbolic and material levels. Pickering (1994) also states that a physical landscape serves as a proxy for the social landscape, specifically through the characteristics of settlement patterns, the spatial and temporal spread of historical occupations, topographic and environmental features, and the characteristics of major drainage areas. Meanwhile, the phrase 'cultural landscape' refers to the interplay of humans and nature that should be seen broadly, including cross-cultural and historical research (Rapoport, 1976). In other words, culture acts as the agent, the natural environment (physical landscape) serves as the medium, and the cultural landscape serves as the outcome (Sauer, 1925).

The aforementioned definitions show that a physical landscape is a critical component of a cultural landscape. In this study, a physical landscape is 
PLANNING MALAYSIA

Journal of the Malaysia Institute of Planners (2021)

defined as any physical factor that shapes human life optimally and can establish durable social traits, regardless of whether it is man-made or natural. The public infrastructure refers to public space, namely a gathering space or social space that is generally open and accessible to the public (Sakip, Akhir and Omar, 2015). Public space should be freely accessible, provides a diverse range of activities, have functions that contribute to its attractiveness and can be used for social activities so that it fosters social interaction (Barrera et al., 2016). A welldesigned public space is critical to connect people to their environment, promotes and provides space for physical activity, improves health and community relations. Public space can be quantified in terms of the availability of facilities, have sufficient areas that accommodate various activities at different times including active physical activities such as sports and recreational activities or for comfort and tranquility. According to Abdul Rahman, Shamsuddin, and Ghani (2015), it is vital for people's comfort or well-being to engage in activities in public spaces that contribute to a vibrant and comfortable community atmosphere. Bagwell et al., (2012) corroborate this assertion by stating that physical landscape design, which includes planning and landscape design, is for the user's comfort, safety, and convenience, as well as having a strong symbolic and aesthetic dimension. A well-distributed and well-linked space are easily accessible physically and aesthetically and can influence the space's positive and security functions (Rad and Ngah, 2013). Additionally, a well-designed public space can accommodate several activities that appeals to a diverse range of users. Additionally, the most critical feature of public space is the provision of possibilities for social contact. When engagement occurs, people develop a stronger sense of belonging to their community and space. This component may be quantified and analysed using data on attendance, social media, and the lives of various social groups.

\section{SOCIAL SUSTAINABILITY}

Social sustainability incorporates the social welfare discourse often seen through the social capital framework. Social sustainability is generally defined as the maintenance and improvement of the well-being of current and future generations (Michael \& Peacock, 2011). According to McKenzie, (2004), this includes equity of access to key services (including health, education, transportation, housing, and recreation), as well as equity across generations, which means that the activities of the current generation also benefit future generations. However, Davidson and Wilson (2009) suggested that social sustainability is a system of cultural relations wherein the positive aspects of different cultures are valued and promoted. According to the Youth Foundation in its framework of creating a new community, social sustainability is defined as the process of creating a sustainable place and succeeds to promote well-being, by understanding what the community needs (Woodcraft, Hackett \& Caistor-Arendar, 2011). 
Nor Zalina Harun \& Najiha Jaffar \& Mazlina Mansor

The Contributions of Public Space to The Social Sustainability of Traditional Settlements

Continuous social interaction is a two-way communication process that involves two or more individuals or groups at a particular place and time (Bardis, 1979; Lotfata \& Ataöv, 2020). In this process, each individual strives and expects each other to understand the behavior of other individuals in their society. The process of adaptation begins with formal or informal meetings, especially in the neighborhood. Through greetings, shaking hands, chatting, visiting, and helping each other, social interaction can initiate friendships (Katiman \& Ismail, 1997; Kader \& Mahmoud, 2019). In this study, the social interaction relationship takes place in public spaces and fosters understanding, tolerance, cooperation, making acquaintances, and helping each other for everyone's benefit. These qualities are essential for the formation of a progressive, integrated, and harmonious society.

\section{RELATION BETWEEN PHYSICAL LANDSCAPE AND SOCIAL SUSTAINABILITY}

We will not be able to achieve a prosperous quality of life if we only assess social sustainability based on non-physical elements such as employment, education, health, governance, and so on. This participation can be enhanced when residents can interact with each other such as being easily contacted, living close to others, and having a suitable space to carry out activities (Festinger et al., 1950). Proximity, both functional and physical is crucial in terms of encouraging social interaction (Widiyastuti \& Ermawati, 2020).In achieving quality social sustainability, physical aspects such as public spaces need to be given due attention. Public space, also known as the physical landscape, plays a key role in determining the prosperity of life and encouraging social participation in society (Roberts, 2003; Moulay, Ujang \& Said, 2017). This means that sustainable social prosperity should integrate physical design with social design as well. For example, providing infrastructure to support social and cultural life, systems involving communities, space for people and space to evolve (González, Henríquez \& Sierra, 2020). In addition, the character of the residential environment and social spaces is also one of the key elements in the foundation of social sustainability to ensure a quality social and community development.

\section{METHODOLOGY STUDY AREA}

Kampung Pulau Duyong is famously known as a seafarer's village developed in the late 16th century. The village is separated from the mainland by the Terengganu River with a distance of 870 metres and the displacement between the two is 495 metres. The settlement is made up of more than 10 villages, namely Pulau Ketam, Kampung Kelab Ayer, Kampung Duyong Sekolah, Kampung Wan $\mathrm{Su}$, and Kampung Pulau Duyong Kecil. Before 1985. Currently with 686 houses, Pulau Duyong has strategic access connected by either land or water and is about 
PLANNING MALAYSIA

Journal of the Malaysia Institute of Planners (2021)

2.7 square kilometres. The locals maintain the Malay culture and way of life, with over $40 \%$ of the population work as fishermen.

Kampung Losong is located near the Kuala Terengganu River with 11 sub-villages opposite Pulau Wan Man. Historically, the villagers of Kampung Losong are well-known for their expertise in marine sciences passed down by the Bugis community. At the same time, the local people of Kuala Terengganu are also skilled in carpentry. As a result, these skills were cleverly combined to produce high-quality boats since the early 18 th and late 19 th centuries. The socioeconomic activities of the Kampung Losong villagers are songket textile businesses, small-scale trading, and fishing. Nowadays, the village is growing exponentially, with more people working in the city and managing small businesses.

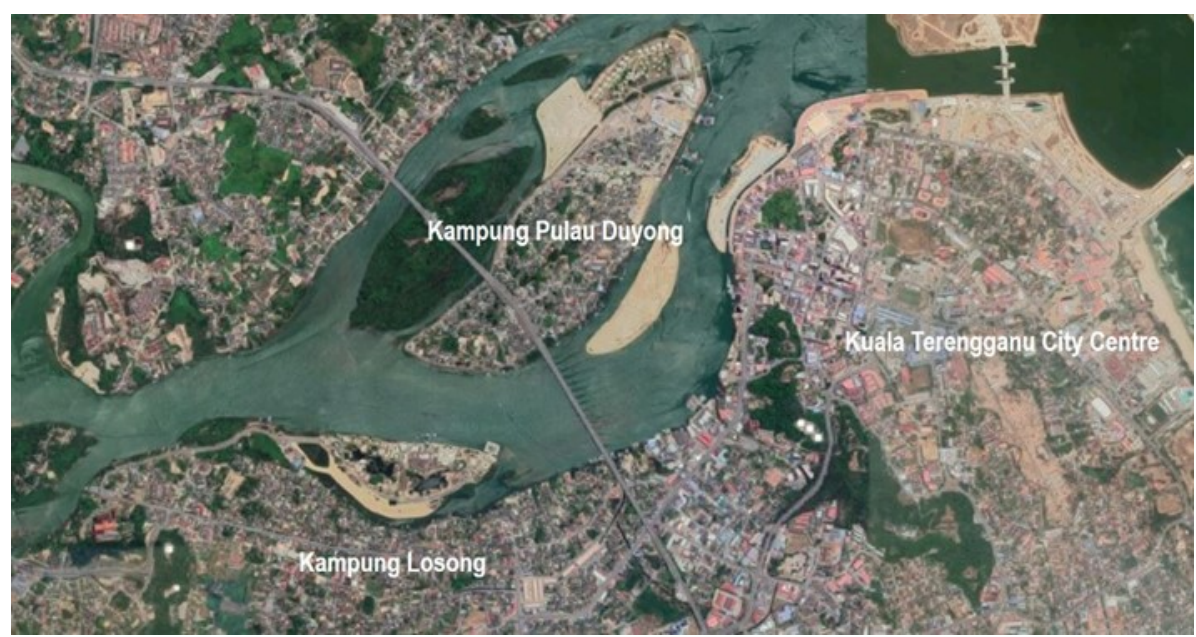

Figure 1: Map of the study area (Source: Google Maps, 2020)

\section{DATA COLLECTION AND DATA ANALYSIS}

The quantitative approach involved a series of survey distributed to over 400 respondents comprising of local residents. Respondents were selected using cluster sampling and they were asked to evaluate the physical attributes criteria affecting social sustainability on a 5-point Likert scale ("1" = strongly disagree and "5" = strongly agree). Cluster sampling is a data collection for a sampling method where the participants of the population are selected at random (Surbhi, 2016). All the respondents were chosen from randomly selected clusters. For this study, the sample representing the units of analysis was local residents living in Kampung Pulau Duyong and Kampung Losong. There are more than 800 local residents' houses in total, where the majority are the Malays. The data gained from the questionnaire survey was analysed using descriptive analysis in the 
Nor Zalina Harun \& Najiha Jaffar \& Mazlina Mansor

The Contributions of Public Space to The Social Sustainability of Traditional Settlements

Social Science Statistics Package (SPSS) version 25. To summarise, descriptive statistics are used to describe data in the form of numerical calculations, charts, and tables. Factor analysis and reliability analysis were adopted in this study to analyse the data. Factor analysis was used to identify the underlying factors affecting the social sustainability of physical attributes.

\section{FINDINGS}

\section{RESIDENTS PROFILE}

The following figures report the results from the questionnaire survey conducted in Kampung Pulau Duyong and Kampung Losong. A total of 400 respondents participated in the survey. Most respondents from Kampung Pulau Duyong $(\mathrm{N}=$ 200 ) were male $(61.5 \%)$, while in Kampung Losong, most residents were female (51\%). A majority of the respondents were between $17-70$ years old with almost fair distribution among the gender. The results indicated that both settlements have a greater number of adult-youth respondents between $26-45$ years old. A large proportion of respondents work in the private sector (KPD, 37\% and KL, $32.5 \%$ ) and self-employed (KPD, 35.5\% and KL, 25.5\%), as seen from both respondents in the survey groups. Less than $20 \%$ are students, housewives, retirees, and unemployed. The majority of respondents are from the middleincome group, earning RM1000-RM2000 a month. However, there is a significant difference, whereby the Kampung Losong population has more income percentage of RM2001-3001 as compared to the Kampung Pulau Duyong population. There are more than $65 \%$ of respondents that have been residing in both villages for 11 years and above. 
Journal of the Malaysia Institute of Planners (2021)

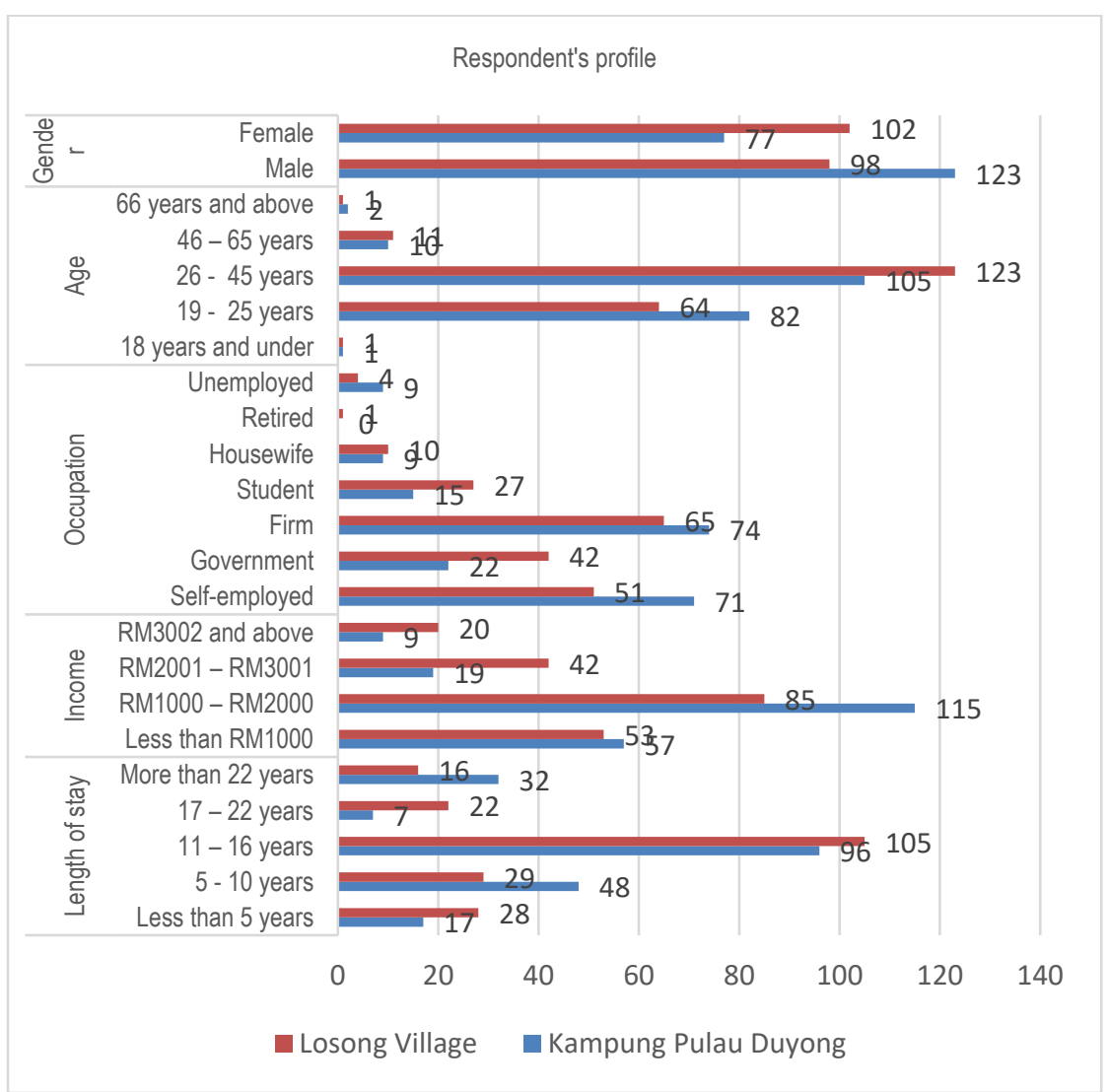

Figure 2: Respondent's profile (Source: Authors, 2019)

\section{TYPOLOGIES OF OPEN SPACES}

The open space available at Kampung Pulau Duyong is a field located strategically near the jetty known as a tourist attraction. The field has an area of 0.2 hectares with a capacity of 300 to 1000 people. There is also a playground for children under 12 years old. The inclusion of passive activities combined with active activities has contributed to the success of the open space in Kampung Pulau Duyong. Among the passive activities identified through observation are observing people, sightseeing, basking in nature, walking, running, kite flying, fishing, and exploring the historic site of Kota Lama Duyong located nearby the field area. Active activities consist of playing football and futsal. Apart from this, various events such as festivals, poetry recitals, forums, and cultural shows are held using the available field area. Furthermore, the recreational facilities offered in the field and other support facilities such as ample seating and shade in the surrounding area often meet the needs of every resident. The location of open 
Nor Zalina Harun \& Najiha Jaffar \& Mazlina Mansor

The Contributions of Public Space to The Social Sustainability of Traditional Settlements

space in front of the river has made Kampung Pulau Duyong unmatched by other recreational areas that usually have an uninteresting view.

While in Kampung Losong, open spaces are grounds and fields located next to the road at the end of the settlement. The Civic Hall and Community Hall facilities located in one place make it easy to accommodate large-scale activities. The open space is dominated by youths and children with active activities in the evening. While public spaces such as platforms or 'pangkin' are dominated by adults and the elderly with a variety of passive activities. With this result, the study found that both settlements have a similar pattern of activities and groups utilising the open space. With adequate facilities, more activities can take place and more people have the opportunity to participate (Omar et al., 2018).

The survey result suggests that social interaction at public infrastructures seems to be influenced by the respondent's background including gender and employment status. Respondents from different groups use public infrastructure for different reasons. Adults and the elderly prefer passive activities such as sitting, reading, eating, and sightseeing. They mostly talk to their friends, share experiences with their peers, and observe people's behavior. This group feels more comfortable in their group without the presence of outsiders. While youths and children are more inclined to explore public space due to their curiosity and enthusiasm in exploring the environment to strengthen their social support, whereas parents use this space to improve their quality of life and life expectancy.

Table 1: Types and nature of activities performed in the public spaces

\begin{tabular}{ll}
\hline Activities & Example \\
\hline & Walking, exercising, relaxing, observing, playing \\
Recreation & Gathering with family and friends, children playing together, \\
In Groups & hawker groups \\
Seasonal Programs & Merdeka celebration, Maulidur Rasul celebration, \\
Daily Activity & competitions, Cultural Day festival \\
Entertainment & Tourists, hawkers, children playing, relaxing, resting \\
Economy & Playing musical instruments, poetry, concerts \\
& Selling daily or during seasonal events \\
\hline
\end{tabular}

\section{DISCUSSION}

Thus, based on the data, this study determined that there are three values or aspects that contribute to the population's social sustainability through the continuity of everyday activities conducted in various types of public places that enable each activity to be conducted constantly. Table 2 summarises the three primary values. 
PLANNING MALAYSIA

Journal of the Malaysia Institute of Planners (2021)

Table. 2: Values of public spaces in accomodating social sustainability

\begin{tabular}{|l|l|l|l|}
\hline Social sustainability indicator & $\begin{array}{l}\text { Factor } \\
\text { loading }\end{array}$ & $\begin{array}{l}\text { \% of variance } \\
\text { explained }\end{array}$ & $\begin{array}{l}\text { Cumulative \% } \\
\text { of the variance }\end{array}$ \\
\hline Recreation space & & $\mathbf{2 . 5 7 9}$ & 63.901 \\
\hline $\begin{array}{l}\text { Have sufficient facilities and } \\
\text { space to accommodate sports } \\
\text { and recreational activities }\end{array}$ & 0.806 & & \\
\hline Communal space & & $\mathbf{2 . 9 1 0}$ & 61.322 \\
\hline $\begin{array}{l}\text { Covers different activities at } \\
\text { different times }\end{array}$ & 0.747 & & \\
\hline $\begin{array}{l}\text { Provides facilities to the public } \\
\text { to enjoy comfort and tranquility }\end{array}$ & 0.614 & & (Source: Authors, 2020) \\
\hline
\end{tabular}

\section{AVAILABILITY OF FACILITIES AND SPACE TO ACCOMMODATE SOCIAL AND RECREATIONAL ACTIVITIES}

All in all, the facilities and area of the public space in Kampung Pulau Duyong and Kampung Losong are sufficient with a good balance to accommodate the capacity of the community among the genders. In addition, it can be used by all groups of people including the elderly, adults and children. The public space in Kampung Pulau Duyong and Kampung Losong can be used by individuals and groups to enjoy outdoor activities, hence improve the quality of social activities among the residents. This coincides with the statement of Sakip, Akhir, and Omar (2015) where they indicated that public space should meet the needs of all its users. The location of public infrastructure by the riverfront too has made Kampung Pulau Duyong a settlement with a relaxed public space. The findings are in line with the study by Abdul Rahman, Shamsuddin, and Ghani (2015) suggesting that public infrastructure should serve as a ceremonial space, node, and landmark.

Apart from a complete infrastructure available such as the field, the children's playgrounds and playfields, the historic sites with open space near Rumah Dato Biji Sura in Kampung Pulau Duyong and Rumah Haji Su in Kampung Losong prove that the cultural and historical heritage aspects of the area have high and unique values. It is an identity that has the capacity to be introduced to the world. Culture and heritage reflect and shape values, beliefs, and aspirations that affirm our identity as citizens. Prominent special features including architecture, physical structure, and culture make the areas of Kampung Pulau Duyong and Kampung Losong unique and worthy of continuous preservation. Moreover, the existence of active space encourages the involvement and integration of the community, which will indirectly foster pride and unity, as well as promote social capital for a longer period ( $\operatorname{Rad} \&$ Ngah, 2014). This can also be done through efforts to emphasise the unique characteristics and identity, strengthens elements and the importance of heritage and culture of the areas. 
Nor Zalina Harun \& Najiha Jaffar \& Mazlina Mansor

The Contributions of Public Space to The Social Sustainability of Traditional Settlements

\section{ACCOMMODATING DIFFERENT ACTIVITIES AT DIFFERENT TIMES}

Studies show that successful public infrastructure is influenced by physical, activity, design, history, and culture that is still practiced. The most vital factor is that public space can accommodate various activities at different times, is to enjoy tranquility comfortably, and have adequate facilities. These factors can create daily interactions that encompass all groups of people, but at the same time maintain privacy among different groups. This study discovers a social perspective on public infrastructure, as revealed by Karimnia \& Haas (2020), and Askari (2014) that the way people use various spaces is important based on different cultures, gender and interests, which then shape social interactions and societal relationships. The results of the study are also in line with Gehl's (2002) statement wherein facilities and equipment are significant factors that play a role in providing satisfaction to users of public infrastructure. Another important factor influencing the success of social sustainability is design (Carmona et al., 2003). This study emphasises that the interior space and public infrastructure environment in traditional settlements should have formal or informal seating amenities to create opportunities for social interaction. As highlighted by Carmona et al. (2003), responsive public infrastructure is a flexible space for various events and as a space that provides a wide selection of activities.

\section{PROVIDES FACILITIES TO THE PUBLIC TO ENJOY COMFORT AND TRANQUILITY}

Based on the observations, the study shows that physical, activity, social, and design factors influence the social interaction of public infrastructure in both settlements of Kampung Pulau Duyong and Kampung Losong. Factors that are seen as fundamental, which create comfort and tranquility are physical, visual appeal, location, security, and accessibility influence social interaction at public infrastructure. The results of this study are in line with Rad \& Ngah (2013) and Widiyastuti \& Ermawati (2020), in which the accessibility of public infrastructure is an influential factor in improving the quality of social interaction. The strategic location of public infrastructure selected by the residents is near the main road and the settlement area. The results of this study also conform with the statements of Pasaogullari and Doratli (2004), and Sugiyama and Thompson (2007) who stated that good public infrastructure is located in neighborhoods and workplaces, easily accessible, and can be monitored from the road.

\section{CONCLUSION}

In conclusion, the provision of complete facilities such as a sufficient supply of seating, dining, trading, activities, and sports are the fundamental factors that attract people to use public infrastructure in traditional Malay settlements. Social 
PLANNING MALAYSIA

Journal of the Malaysia Institute of Planners (2021)

interaction with each other, sharing ideas, viewing scenery, practicing religious beliefs, and enjoying leisure time can improve the quality of life as well as emotional stability formed from attitudes and successful public space designs. A successful public infrastructure is also a space that is easily accessible, establishes social connections, provides a variety of events and activities, with an attractive design, and creates a sense of belonging. Lastly, social relationships are crucial for communities in a settlement because strong community relationships will encourage individuals to cooperate in achieving prosperity. This study suggests that conservation efforts focused on the physical landscape is intended to give ideas and efforts regarding the importance of preserving social sustainability in a traditional Malay settlement. Preservation and conservation efforts of the physical landscape are important because it reflects the sustainability of a society with an identity. This can be achieved by revealing the community activities that are still practiced in traditional settlements. This study is a branch of cultural landscape knowledge whereby traditional settlement is a platform that connects two main elements, namely human activities and the physical landscape. The physical landscape is difficult to replace or restore if it diminishes. Its loss will indicate the non-existence of a settlement's identity. Hence, this study focuses on providing insights and recommendations to maintain the quality of the physical landscape with an emphasis on public spaces available in traditional Malay settlements. It is suggested that further research be carried out within the field of social sustainability, Malay cultural landscape, and its related areas. Several research topics that can be investigated related to the study are as follows: (i) the study on the determinant factors to enhance other sustainable values such as economy and environment, (ii) the behavioural response in experiencing the life in traditional Malay settlements, (iii) the non-physical characteristics of the Malay cultural landscape contributing to the enhancement of social sustainability.

\section{ACKNOWLEDGEMENTS}

The authors would like to thank the Institute of the Malay World and Civilization, The National University of Malaysia. This work was accomplished in part with funding from Grant FRGS/1/2019/WAB03/UKM/02/1

\section{REFERENCES}

Ariffin, N. F. M. (2007). Role of cultural landscape in improving the identify of the Kuala Terengganu Town centre as a Malay historic town (Doctoral dissertation, Universiti Teknologi Malaysia).

Askari, A. H. (2014). Assessment of Urban public spaces: Cases of Kuala Lumpur city center (Doctoral dissertation, University of Malaya).

Authority, L. G. (2011). Pelan Induk Kampung Tradisional dan Petempatan Tersusun di Dalam Kawasan Pihak Berkuasa Tempatan Semenanjung Malaysia.

Bagwell, S., Evans, G., Witting, A., \& Worpole, K. (2012). Public space management report to the intercultural cities research programme. 
Nor Zalina Harun \& Najiha Jaffar \& Mazlina Mansor

The Contributions of Public Space to The Social Sustainability of Traditional Settlements

Bardis, P. D. (1979). Social interaction and social processes. Social Science, 54(3), 147167.

Barrera, F., Reyes-Paecke, S., Harris, J., Bascuñán, D., \& Farías, J. M. (2016). People’s perception influences on the use of green spaces in socio-economically differentiated neighborhoods. Urban Forestry \& Urban Greening, 20, 254-264.

Berglee, R. (2012). World regional geography: People, places and globalization.

Bobek, H., \& Schmithüsen, J. (1998). A paisagem e o sistema lógico da geografia. CORRÊA, RL.

Brown, G., \& Brabyn, L. (2012). An analysis of the relationships between multiple values and physical landscapes at a regional scale using public participation GIS and landscape character classification. Landscape and Urban Planning, 107(3), $317-$ 331.

Davidson, M. (2009). Social sustainability: a potential for politics? Local Environment, 14(7), 607-619.

Festinger, L. (1950). others, Theory and Experiment in Social Communication. Ann Arbor.

Gehl, J. (2002). Public spaces and public life: City of Adelaide, 2002. City of Adelaide, Adelaide.

Ghoomi, H. A., Yazdanfar, S. A., Hosseini, S. B., \& Maleki, S. N. (2015). Comparing the components of sense of place in the traditional and modern residential neighborhoods. Procedia-Social and Behavioral Sciences, 201, 275-285.

González, D., Henríquez, B., \& Sierra, L. (2020). Evaluation of the Social Sustainability of Infrastructure Projects: A Case Study of Urban Road Improvement in Southern Chile. In IOP Conference Series: Earth and Environmental Science (Vol. 503, No. 1, p. 012002). IOP Publishing.

Jasinski, E., Morton, D., DeFries, R., Shimabukuro, Y., Anderson, L., \& Hansen, M. (2005). Physical landscape correlates of the expansion of mechanized agriculture in Mato Grosso, Brazil. Earth Interactions, 9(16), 1-18.

Kader, A., \& Mahmoud, R. A. (2019). Strategies for Urban Residual Areas as a Planning Tool: Towards Achieving Sustainable Built Environment by Connecting Neighbourhoods. In IOP Conference Series: Earth and Environmental Science (Vol. 329, No. 1, p. 012018). IOP Publishing.

Karimnia, E., \& Haas, T. (2020). Appropriation of Public Space. Companion to Public Space.

Leibenath M, Gailing L (2012) Semantische Anna herung an dieWorte, Landschaft "und, Kulturlandschaft “". In: SchenkW, Ku'hn M, Leibenath M, Tzschaschel S (eds) SuburbaneRa üme als Kulturlandschaften. Verlag der ARL, Han-nover, pp 5879.

Lotfata, A., \& Ataöv, A. (2020). Urban streets and urban social sustainability: a case study on Bagdat street in Kadikoy, Istanbul. European Planning Studies, 28(9), 17351755.

McKean, E. (2005). The new Oxford American Dictionary (Vol. 2). New York: Oxford University Press.

McKenzie, S. (2004). Social sustainability: towards some definitions.

Michael, Y. M. A. K., \& Peacock, C. J. (2011). Social Sustainability: A Comparison of Case Studies in UK, USA and Australia. 
Moulay, A., Ujang, N., \& Said, I. (2017). Legibility of neighborhood parks as a predicator for enhanced social interaction towards social sustainability. Cities, 61, 58-64.

Omar, D., Ramlee, M., Yunus, R. M., \& Samadi, Z. (2018). Urban Public Space Revitalisation Strategies for George Town World Heritage Site. EnvironmentBehaviour Proceedings Journal, 3(7), 285-291.

Pasaogullari, N., \& Doratli, N. (2004). Measuring accessibility and utilization of public spaces in Famagusta. Cities, 21(3), 225-232.

Pickering, M. (1994). The physical landscape as a social landscape: a Garawa example. Archaeology in Oceania, 29(3), 149-161.

Rad, V. B., \& Ngah, I. (2013). The role of public spaces in promoting social interactions. International Journal of Current Engineering and Technology, 3(1), 184-188.

Rad, V. B., \& Ngah, I. B. (2014). Assessment of quality of public urban spaces. Science International, 26(1).

Rahman, N. A., Shamsuddin, S., \& Ghani, I. (2015). What makes people use the street? Towards a liveable urban environment in Kuala Lumpur City Centre. ProcediaSocial and Behavioral Sciences, 170, 624-632.

Rasdi, M. T. H. M. (2011). Krisis pemikiran seni bina Malaysia. Penerbit UTM Press.

Relph, E. (1976). Place and placelessness (Vol. 67). London: Pion.

Rostam, K., \& Ismail, W. M. W. (1997). Pola Interaksi Sosial di Kawasan Perurnahan Terancang di Bandar Baru Bangi. Akademika, 50(1).

Sakip, S. R. M., Akhir, N. M., \& Omar, S. S. (2015). Determinant factors of successful public parks in Malaysia. Procedia-Social and Behavioral Sciences, 170, 422-432.

Sauer, C. (1963). 0.(1925). The morphology of landscape. University of California publications in geography, 2(2), 19-54.

Sherrouse, B. C., Clement, J. M., \& Semmens, D. J. (2011). A GIS application for assessing, mapping, and quantifying the social values of ecosystem services. Applied Geography, 31(2), 748-760.

Sugiyama, T., \& Thompson, C. W. (2007). Older people's health, outdoor activity and supportiveness of neighbourhood environments. Landscape and Urban Planning, 83(2-3), 168-175.

Wei, L. (2015). Research on the localization method of protecting traditional village landscape: a case study on tangyin. International Archives of the Photogrammetry, Remote Sensing \& Spatial Information Sciences, 40.

Widiyastuti, D., \& Ermawati, H. (2020). The Availability of Social Space in The Urban Yogyakarta, The Case Study of Umbulharjo District. E\&ES, 451(1), 012103.

Woodcraft, S., Hackett, T., \& Caistor-Arendar, L. (2011). Design for social sustainability: A framework for creating thriving new communities. Future Communities.

Received: $5^{\text {th }}$ November 2021. Accepted: $5^{\text {th }}$ December 2021 